\title{
AJ Cronin and The Citadel: did a work of fiction contribute to the foundation of the NHS?
}

\author{
S O'Mahony \\ Consultant Physician/Gastroenterologist, Cork University Hospital, Cork, Ireland
}

\begin{abstract}
AJ Cronin (1896-198I) was a Scottish-born doctor-turned-novelist whose most famous novel is The Citadel, published in 1937. The book describes the struggles of an idealistic young doctor working in Wales and London in the 1920s and 30s. The novel was a global bestseller and its portrayal of a largely ineffective, corruption-ridden system of healthcare is thought to have directly influenced the foundation of the National Health Service in 1948. The Citadel anticipates such phenomena as evidence-based medicine and continuing medical education. This paper argues that the novel was never intended as propaganda for a statecontrolled national health service. On the contrary, Cronin was against state control. Analysis of the novel is informed by recent biographical revelations about Cronin and the blurring of the margin between fact and fiction in Cronin's life and work is examined.
\end{abstract}

KEYWORDS AJ Cronin, The Citadel, Adventures in Two Worlds, National Health Service, tuberculosis

\author{
Correspondence to S O'Mahony \\ Cork University Hospital \\ Wilton, Cork, Ireland \\ tel. +353 (0)2I 4922378 \\ e-mail Seamus.omahony@hse.ie
}

DECLARATIONS OF INTERESTS No conflicts of interest declared.

\section{INTRODUCTION}

AJ Cronin (1897-198I), an author little known to those under the age of fifty, was arguably the most successful novelist writing in English in the 1930s. His best known novel, The Citadel, was published in 1937.' The book paints an unflattering portrait of some parts of British medicine in the interwar years. It is widely believed that the book influenced the result of the 1945 general election in Britain and the subsequent establishment of the National Health Service (NHS) by the Labour government in 1948.

\section{BRIEF BIOGRAPHY}

Cronin was born in Cardross, Scotland in 1896. His father was of Irish descent and Catholic and his mother's family was Protestant. Cronin's father died when he was seven years old, forcing Cronin and his mother to move in with her parents. He excelled academically and at sports and won a Carnegie Foundation Scholarship to study medicine at Glasgow University, where he graduated in 1919. He subsequently worked as a GP in South Wales, moving then to London, where he established a successful private practice. In his mid-30s, he experienced some form of crisis - ascribed to peptic ulcer in his autobiography ${ }^{2}$ - and sold his practice, with plans to write a novel. This he duly did and the resulting book, Hatter's Castle, was accepted by the first publisher he sent it to (Victor Gollancz) and was an immediate bestseller. He never returned to medical practice. The 1930s were his most productive and successful years;

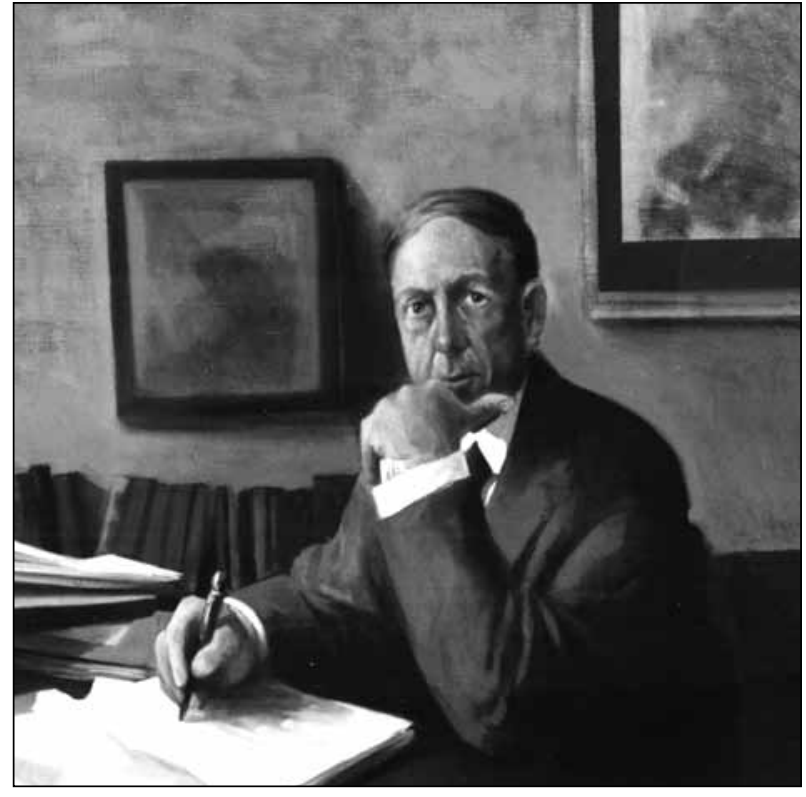

FIGURE I AJ Cronin (1897-198I) by Stephen Conroy. Image courtesy of West Dunbartonshire Council.

following the success of Hatter's Castle, he wrote two more bestsellers, The Stars Look Down, and The Citadel. His novels were successfully adapted for film and Cronin became a wealthy man. He spent much of the subsequent war years in America and eventually settled permanently in Switzerland. Although he published several more novels until the early 1970s, he never repeated his success of the 1930s. 


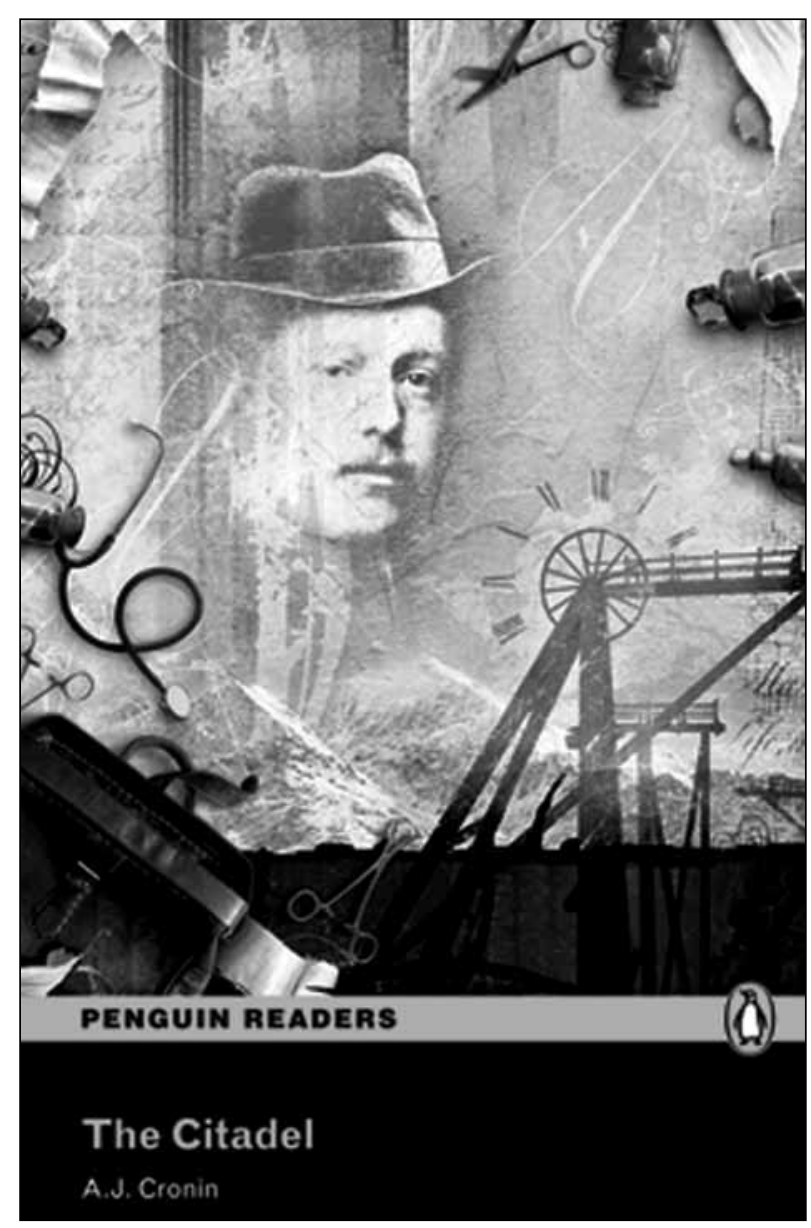

FIGURE 2 Book cover from the Penguin Reader publication (2008). Image courtesy of Pearson.

Cronin's novels have common themes: the struggle of poor Catholic scholarship boys to overcome sectarian bigotry and make their way in the world, usually through academic achievement; idealistic young men (usually doctors) losing their moral compass through the temptations of money and sex; Catholic themes of sin, guilt and redemption. He recycled these themes and plots in his less successful later novels. Cronin is probably best known to the television generation as the author of the Adventures of a Black Bag stories, whose characters formed the basis for the popular Dr Finlay's Casebook TV series which initially ran from 1962 to 1971.

\section{THE CITADEL: A SUMMARY}

The Citadel tells the story of Andrew Manson, an idealistic young Scottish doctor, modelled closely on Cronin himself. Manson takes up a post as a general practioner (GP) assistant in Drineffy, a Welsh mining town. He is shocked to learn that his principal, Dr Page, has been completely incapacitated by a stroke and will clearly never work again. Page's wife (sister in the second edition of the novel) attempts to conceal this fact, while exploiting Manson. Manson works for the miners' medical-aid club, but increasingly dislikes this work. He becomes friendly with the cynical Denny, another assistant GP, who tells him that contaminated water has led to several deaths from typhoid in the town. The senior doctors show no interest in the problem and Manson and Denny eventually blow up the old sewer, forcing the authorities to build a safe water supply. Manson marries a local schoolteacher, Christine, and impresses the townspeople with his medical skill. He correctly diagnoses and successfully treats hypothyroidism ('myxoedema madness') in a man who suddenly became violent and who is on the brink of being committed to an asylum by the other doctors. Manson saves a baby's life during a difficult delivery and is rewarded with a large cheque by the baby's father. Dr Page's sister is angered by this gift and Manson resigns. $\mathrm{He}$ moves to a better post in another Welsh town, Aberlaw, but soon runs into trouble. The head doctor expects to receive part of his salary and he refuses to sign sick notes for malingering miners. Manson studies hard for the MRCP examination, which he passes, impressing his examiner, the distinguished and sympathetic Sir Robert Abbey. He saves a miner's life following a mine accident by amputating his arm. Manson's wife becomes pregnant, but loses the baby: she is told she will never have children. He becomes interested in lung disease caused by coal dust and carries out research which leads to an MD degree. Manson's enemies in the town accuse him of using animals for experiments without obtaining a licence from the Home Office. Although he is exonerated, he resigns his post. Appointed Chief Medical Officer for the Mining Fatigue Board, he soon discovers that the Board, controlled by the mine owners, is filled with place-men, apart from the honourable exception of Sir Robert Abbey. The employers want to distract him from his work on coal-induced lung disease and Manson becomes bored, with little to occupy him. He befriends an idealistic young microbiologist, Hope, who also works for the Board. After less than a year, Manson resigns his post and buys a run-down practice in London. He struggles at first, but is soon busy and successful. Manson succumbs to the temptations of money and sex, attracting rich neurotic private patients and he embarks on an affair. He also befriends two unscrupulous society doctors, Hamson and Ivory and abandons his high ethical standards, becoming wealthy from fee-splitting and exploiting rich neurotics. Both Christine and his old friend Denny try to persuade him back to his old ethical ways (the significance of the book title becomes clearer when Christine remonstrates with Manson: 'Don't you remember how you used to speak of life, that it was an attack on the unknown, an assault uphill - as though you had to take some castle that you knew was there, but couldn't see, on the top.'). Manson meets Stillman, an American scientist, who, although not medically qualified, has done groundbreaking work on tuberculosis. He 
finally comes to his senses following the death of a patient after a botched operation by the incompetent Ivory. Manson had referred the man to lvory and had assisted at the operation. Ivory is also revealed to be an abortionist. Manson vows to practice honest, scientific medicine and plans with his friends Denny and Hope to set up a new clinic together. He sells his practice, but tragedy strikes when Christine is run over by a bus. The vengeful Ivory reports Manson to the General Medical Council for referring a patient with tuberculosis (the daughter of his old friend Con Boland) to Stillman, who is not a medical doctor. Manson delivers an impassioned speech on the failures of British healthcare and the Council, which includes his old patron Sir Robert Abbey, exonerate him. He leaves London for a town in the Midlands, where he sets up a clinic with Denny and Hope.

\section{THE IMPACT OF THE CITADEL}

The Citadel was an immediate success, selling over 150,000 copies in Britain in the first three months after publication and 10,000 copies a week for the rest of the year. ${ }^{3}$ It was equally successful in the US and in Europe, particularly in Germany and Russia. Readers in Communist Eastern Europe admired the technical modernisation and social criticism, while in Nazi Germany the book was regarded as useful anti-British propaganda. ${ }^{4}$ The novel's success was partly due to Victor Gollancz's astute marketing of the book. He launched a major advertising campaign and the book became a favourite of book clubs, including Gollancz's own Left Book Club. He successfully sold the book as an exposé of corrupt institutions. A Gallup poll conducted in 1938 reported that The Citadel 'impressed' more people than any other book except the Bible. ${ }^{4}$ The BBC broadcast ten readings from the novel in 1938. It went on to become a successful film, directed by King Vidor, garnering four Oscar nominations, including best actor (Robert Donat) and best picture. It was the most commercially successful film in Britain in 1939. ${ }^{4}$

Contemporary reviews of the book however were not uniformly positive. Leonora Eyles, writing in the Times Literary Supplement, accused Cronin of demonising the entire medical profession:

All over the country today are county and municipal officers who care less for fees than for healing; in general practice are insignificant men and women living devoted, anxious lives with only fourteen days a year away from the clamorous telephone by day and night. In Harley Street are men who might stand by Lister without shame. ${ }^{5}$

It is claimed, with some justification, that the book strongly influenced the result of the 1945 British general election, when the voters rejected the war hero
Churchill in favour of the less charismatic social reformer, Labour leader Clement Attlee. ${ }^{6}$ This Labour government established the NHS in 1948. Many of the seeds of the NHS were sown in Tredegar, home town of the NHS's architect, Aneurin Bevan. When Bevan introduced the NHS he wrote: 'All I am doing is extending to the entire population of Britain the benefits we had in Tredegar for a generation or more. We are going to 'Tredegarise' you'. ' Cronin spent three formative years in this town ('Aberlaw' in The Citadel) and although there is no evidence that they met, it seems likely that they did.They were certainly exposed to the same influences and the Medical Aid Societies set up by the miners' unions in South Wales inspired Bevan to extend free healthcare to the entire nation. ${ }^{3}$ In Adventures in Two Worlds, Cronin says:

In actual fact this scheme can definitely be regarded as the foundation of the plan of socialised medicine which was eventually adopted by Great Britain. Aneurin Bevan, the Minister of Health, who was mainly responsible for the national project, was at one time a miner at Tredegar, and here, under the local aid organisation, the value of prompt and gratuitous treatment for the worker was strongly impressed upon him. ${ }^{2}$

It is difficult to quantify the influence of The Citadel. Cronin was no socialist, complaining that people who had free healthcare did not value it. Nevertheless, its timing - published in 1937 - was opportune. The 1920s and $30 \mathrm{~s}$ were decades of scientific and social advance, yet British medicine was still essentially Victorian in its ideas and practice. The Second World War accelerated the process of change and it is not surprising that when the war finally ended, the British electorate unsentimentally cast off Churchill. The theme of The Citadel is the struggle of the idealistic young hero against the medical establishment, which is corrupt, venal, unscientific and self-serving. Private practice is shown to be a shabby, money-grabbing business, exploiting the rich and gullible. Quack treatments are commonplace and most doctors are too lazy to keep themselves abreast of scientific developments. GPs are portrayed as ignorant drudges, peddling useless and outdated drugs ('no more than a poultice mixer or medicine slinger'). They rarely cooperate with each other, interested only in protecting their own interests. Cronin, through Manson, almost prophesies the advent of evidence-based medicine ('an absolute allegiance to the scientific ideal, no empiricism, no shoddy methods, no stock-prescribing, no feesnatching, no proprietary muck, no soft-soaping of hypochondriacs') and continuing professional education ('There ought to be a law to make doctors up to date ...compulsory post-graduate classes - to be taken every five years'). He had his doubts, however, about socialised medicine: 
There is certainly value in the scheme [The Miners' Medical Aid Society], but it also has its defects, of which the chief one, in Tredegar, was this - with complete carte blanche in the way of medical attention, the people were not sparing by day or night, in "fetching the doctor". A malingerer's and hypochondriac's paradise.

Manson delivers a long speech to his friends Denny and Hope on the inadequacies of the hospital system, particularly in London. He seems to suggest some form of state control:

And what's being done? Zero, absolute zero. We just drag on in the old, old way, rattling tin boxes, holding flag days, making appeals, letting students clown for pennies in fancy dress. One thing about these new European countries - they get things done.

One assumes these 'new European countries' are Hitler's Germany and Mussolini's Italy. The final chapter, when Manson, in a speech from the dock-style oration, addresses the General Medical Council, could be read on its own as a political manifesto, summarising Cronin/ Manson's views on the failures of the system:

Go to the beginning: think of the hopelessly inadequate training doctors get ...We ought to be arranged in scientific units. There ought to be compulsory post-graduate classes. There ought to be a great attempt to bring science into the front line, to do away with the old bottle-of-medicine idea, give every practitioner a chance to study, to co-operate in research. And what about commercialism? - the useless guinea-chasing treatments, the unnecessary operations, the crowds of worthless pseudo-scientific proprietary preparations we use - isn't it time some of these were eliminated? The whole profession is far too intolerant and smug. Structurally, we're static.

Cronin's main argument, therefore, is not for the establishment of a state-controlled nationalised health service, but rather for education, training and reverence for the scientific method.

For a twenty-first century reader, Cronin's clinical details are unfamiliar: the radical, allegedly scientific treatments espoused by Manson for tuberculosis seem to modern readers to be as ineffective as the quack patent medicines he rails against. Stillman, the charismatic American, is portrayed as achieving remarkable results in patients with pulmonary tuberculosis by inducing a pneumothorax in the infected lung. In little over a decade and a half after the publication of The Citadel, effective antibiotic therapy for tuberculosis would become available making the idea of inducing pneumothorax to 'rest the lung' appear archaic, although in many cases it was effective. The character of $\mathrm{Dr}$ Thoroughgood, the chest physician who, although kind and hard-working, is portrayed as irredeemably old-fashioned and outdated:

But in treatment, his tidy mind resented the intrusion of the new. He would have nothing to do with tuberculin, holding that its therapeutic value was still completely unproved. He was chary of using pneumothorax and his percentage of inductions was the lowest in the hospital. He was, however, extremely liberal in the matter of cod-liver oil and malt. $\mathrm{He}$ prescribed it for all his patients.

Ironically, Thoroughgood's practice strikes the modern reader as more evidence-based than Manson's or Stillman's. The description of the botched operation by Ivory is unconvincing: exactly what sort of 'cyst' did this patient bleed from? It is not clear how a polyclinic comprising a physician, a surgeon and a microbiologist would bring cutting-edge medical care (our idea of 'specialised cooperation') to a market town in the West Midlands.

\section{CRONIN THE WRITER: FACT AND FICTION}

In a recent biography ${ }^{3}$ (only the second) of Cronin, the author laments the fact that while contemporaries such as Graham Greene and Evelyn Waugh are fêted and are still read and in print, Cronin has all but been forgotten. There is a simple explanation for this; Cronin was a good writer, but not a great one. His skill was for narrative, combined with a sort of hectoring moral righteousness. He had a good ear for regional dialect and the dialogue of the Welsh miners is convincing and authentic. The reasons for the success of The Citadel were threefold: a) timing, b) the novel's accurate portrayal of a dysfunctional medical care system easily recognisable to its readers, and c) Gollancz's genius for promotion. On the week of its publication in 1937, Gollancz boldly sent 200 copies to the British Medical Association, who were in annual conference in Belfast. ${ }^{4}$ He ran regular newspaper advertisements, announcing ever-increasing sales of the book.

The fact remains that Cronin's style is pedestrian 'serviceable', according to one charitable commentator. ${ }^{4}$ Exclamation marks are scattered throughout both the third-person narrative and dialogue. The book is full of antique 1930s slang - 'by Jove!', 'dashed', 'confound it!' His characters, such as Manson's wife, Christine, are two-dimensional and clichéd. Many key scenes, such as the blowing up of the infected sewer, the arm amputation in the mine and Christine's miscarriage and death, are pure melodrama. AJ Cronin's writing is almost completely devoid of humour. His attempts at light relief, such as the scene when Con Boland's jalopy collapses, are simply embarrassing. Manson is tedious, 


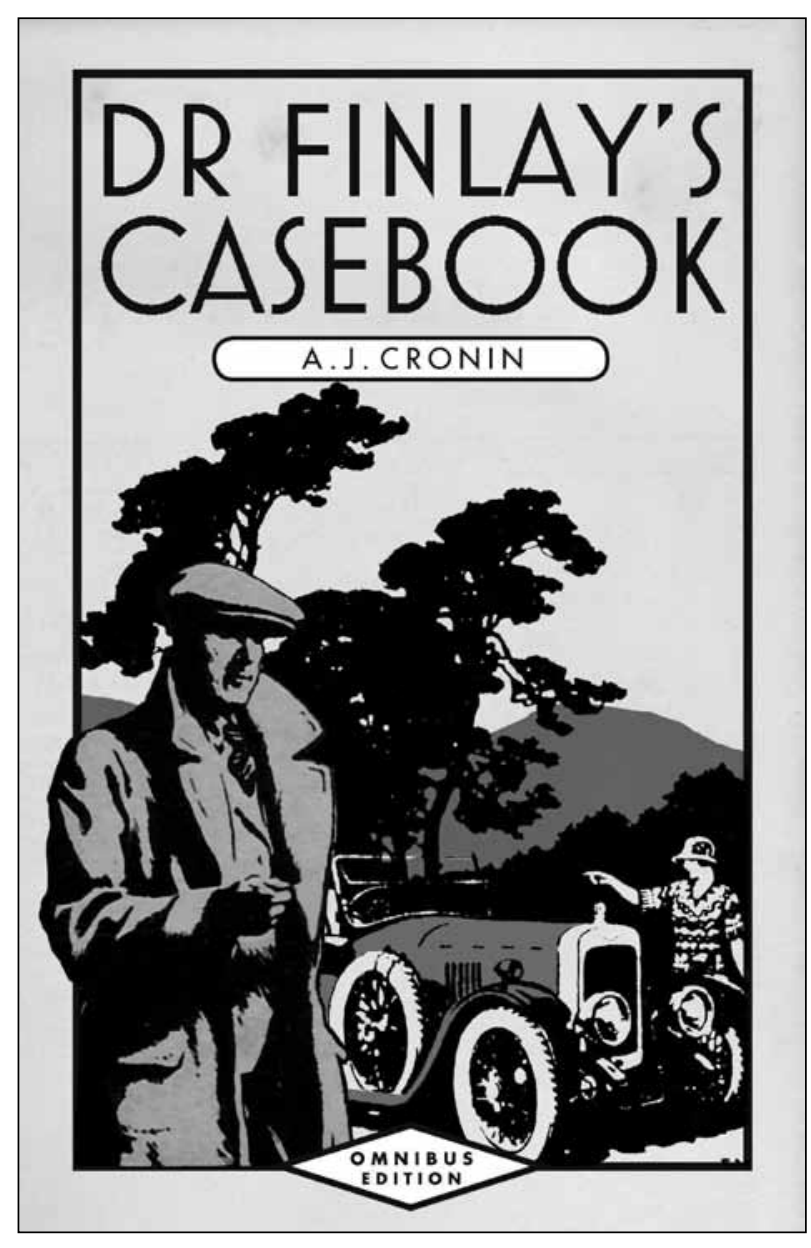

FIGURE 3 Dr Finlay's Casebook, based on Cronin's autobiography, became a highly popular BBCTV series in the 1960s and was revived by ITV in the 1990s. Books of the series continue to sell. Image courtesy of Birlinn Ltd.

opinionated, judgmental and self-righteous. He is given to sermonising at great length - as was Cronin, particularly in Adventures in Two Worlds. In 194I, John T Frederick, writing in The English Journal on Cronin, asked:

Can a novel which is dull and graceless in style, devoid of humour, obvious and often clumsy in construction, frequently mediocre in characterization, yet deserve serious consideration as a work of fiction? Can a poor writer be a great novelist? ${ }^{8}$

Cronin did not have a vocation for medicine; he found it dull and abandoned it without much regret. He himself admitted as much when he told Victor Gollancz that Hatter's Castle was 'written in the Scottish Highlands during August, September and October of 1930 and represents a rather fumbling attempt, upon my part, to escape from the neat little pathways of medicine into the unconfined and, to my mind, infinitely more attractive pastimes of literary art'. ${ }^{3}$ He later admitted to an American audience that the success of this book gave him the opportunity 'to leave my practice which I hated and take up the job of writing which I love'. ${ }^{3}$ His memoir, Adventures in Two Worlds, contains so many untruths and inconsistencies that it is now regarded as essentially a fictionalised impression of his life. His biographer Alan Davies makes it clear that it should now be read as a novel, and indeed it rehashes many of the themes of his novels. Adventures in Two Worlds and The Citadel contain near-identical set-pieces, such as Manson/Cronin's MRCP viva voce examination. It seems as though his fiction is autobiography and his autobiography is fiction. Many of the characters in The Citadel were immediately recognisable as the 'real' persons on whom they were based: Mrs Hinde-Arnold, widow of Dr William Hinde, immediately recognised herself as 'Blodwyn Page'. She threatened a libel action against Cronin and Gollancz; this was withdrawn following a formal written apology from Cronin and a substantial revision of the character in the second edition of The Citadel, where Blodwyn Page is now the sister, rather than the wife of Dr Page, and is portrayed more sympathetically. ${ }^{3}$ Dr Edwin Davies, chief medical officer of the Tredegar Medical Aid Society and the model for 'Dr Llewellyn' made a similar threat but withdrew it. ${ }^{3}$ Chapter 18 of Adventures in Two Worlds is almost identical to chapter 10 (part 2) of The Citadel. Sir Robert Abbey (in The Citadel) is clearly based on Lord Dawson of Penn, the Royal Physician who famously expedited the demise of King George $V$ and becomes the 'real' historical figure, in Adventures in Two Worlds. The devious (and fictional) Dr Gadsby appears in both books. Ivory was based on Ivor Back, a fashionable surgeon, whose wife, Barbara, was one of Somerset Maugham's closest friends.

This blurring of the boundaries between fiction and memoir is a very modern, even fashionable, phenomenon. David Shields's Reality Hunger is subtitled 'a manifesto' to reflect this distortion. ${ }^{10}$ Although Cronin is too middlebrow for Shields, who prefers his blurring to be more knowing and postmodern, his flexible approach to fiction and autobiography complements Shields's. 'The books that most interest me sit on a frontier between genres', writes Shields in Reality Hunger. Although Cronin's biographer advises that Adventures in Two Worlds should be read as a novel, ${ }^{3}$ most readers have consumed it as straight, factual autobiography. Surawicz and Jacobson, writing in Doctors in fiction state that Cronin "practised in the Scottish mining town of Tannochbrae.." There is no such town. Cronin also describes in Adventures in Two Worlds working as assistant to a Dr Cameron. Dr Cameron, of course, is no more real than Tannochbrae. Cronin recycled these places and characters for the Adventures of a Black Bag stories. These fictional places and characters formed the basis for Dr Finlay's Casebook, the television series which made Cronin globally famous (although Cronin did not actually write the scripts). One suspects that laziness, rather than some form of playful literary postmodernism 
accounted for Cronin's frequent recycling of plots and characters. (The 'myxoedema madness' story is re-told in at least three books.) Cronin was definitely not an experimental writer and had little patience with modernism, much less postmodernism. Cronin told his publisher that the book 'will not be an autobiography but will be full of incident, tender, moving and dramatic, with just that medical flavour which readers love, a really warm and interesting book. ${ }^{3}$ Despite this assertion, Gollancz marketed the book as an autobiography, mainly for commercial reasons.

Some details of Cronin's life are stranger and more singular than the events described in his 'autobiography' and novels. Cronin's abandonment of medicine was, according to the recent biography, even more dramatic than described in Adventures in Two Worlds. Like Manson, he saved the life of a sick child (he performed a tracheotomy on a child about to suffocate from diphtheria). The child's father was naturally very grateful and invited Cronin to join an investment group which led to a profit of $£ 80,000$ for Cronin. ${ }^{3} \mathrm{He}$ thus became a wealthy man and gave up medicine forever. He could have lived comfortably even if he had never written novels. The combination of this huge windfall and the massive sales of his books made him very rich. Interestingly, the 'Cronin' character in Adventures in Two Worlds is similarly advised to invest, but loses most of his money; the moral of the story, of course, is that money doesn't make you happy. Cronin the writer never really struggled for success. His first novel was accepted by the first publisher he sent it to and was an immediate bestseller.

Cronin was never quite comfortable with his good fortune and his later books are tinged with a sense of guilt, regret and self-loathing. His finest later work, The Judas tree, is the best example of Cronin's keen instinct for $\sin ^{.2}$ The hero, a once idealistic Scottish doctor, abandons the Spartan but straight road of medicine for an easy life of money and comfort in exile in Switzerland. He betrays and abandons his innocent sweetheart and even manages to do the same many years later to the daughter (by another man) of this woman. He cannot bear the guilt and hangs himself - from a Judas tree. Cronin had uneasy relationships with women and in his novels the female characters are poorly realised. The recent biography of Cronin by Davies makes frequent reference to the ' 1976 autobiography', which was never completed or published and apparently deals mainly with his unhappy marriage and parallel relationship with Nan, the Cronins' nanny and housekeeper. ${ }^{3} \mathrm{He}$ married young, under the mistaken impression that his wife-tobe was pregnant, and regretted the decision thereafter. The relationship was strained, exacerbated by his wife's mental fragility and Cronin's indifference to her. $\mathrm{He}$ maintained a long-running (apparently chaste) relationship with $\mathrm{Nan}$. His wife eventually developed dementia and spent her remaining years in institutional care. After her death, Cronin and Nan lived openly as a couple. Nevertheless, in Adventures in Two Worlds, Cronin proudly boasted of his own marital bliss: 'If I speak feelingly here, it is because of the happiness which my own marriage has brought me, a happiness due to that stroke of fortune which gave me a wife so finely moulded by her early training; so patient, self-sacrificing, and wise; above all, so completely staunch in every vicissitude of our partnership of thirty years that life without her would be unthinkable.'

Cronin's life is thus of interest, as it provides the key themes for his fiction: the poor scholarship boy who struggles against bigotry and poverty to qualify as a doctor; the idealistic young doctor struggling against ignorance and a corrupt medical hierarchy; the disillusioned middle-aged man who, despite his wealth and comfort, longs for the excitement and moral certainties of his life as a doctor; the devout Catholic who has betrayed his wife and his principles.

Cronin's work declined creatively after the 1930s. He never repeated the success of the 1930s novels, Hatter's Castle, The Stars Look Down and The Citadel. In a perceptive essay, ${ }^{4}$ McKibbin concluded that Cronin was a good genre novelist, but nothing more. McKibbin places The Citadel firmly in the medical hero genre and points out that Cronin probably drew inspiration from Sinclair Lewis's Arrowsmith, the plot and themes of which share many similarities with The Citadel. Davies portrays an author more concerned with royalty cheques than artistic inspiration. ${ }^{3}$ He lacked curiosity. Despite living for many years in the US, he never used this experience for his fiction. He lived to the age of 84 , yet his fiction draws little from the last 50 years of his life. Like Waugh, the post-war world horrified Cronin, but unlike Waugh this horror did not inform his writing. In reactionary old age he came to accept, like Somerset Maugham (whom he greatly admired), that his talent was essentially middlebrow.

\section{THE ENDURING INFLUENCE OF THE CITADEL}

Did The Citadel really have such an influence on the foundation of the NHS? It is difficult to judge. Manson considers, then rejects, some form of nationalised healthcare: "It's the system", he thought savagely, "it's senile. There ought to be some better scheme, a chance for everybody - say, oh, say State control!" Then he groaned, remembering Doctor Bigsby and the MFB [Mining Fatigue Board]. "No, damn it, that's hopeless bureaucracy chokes individual effort - it would suffocate me".' The book describes a severely dysfunctional medical system, it was a massive international bestseller, adapted into a successful film and, published shortly before World War II, was perfectly timed. We can 
cautiously conclude that it did significantly colour the views of the millions of people who read the book and saw the film: the 1938 Gallup poll clearly states the impression The Citadel made on its readers. The book also inspired many young people to pursue a career in medicine. Did Cronin intend the book to be a rallying call for a nationalised state-controlled health service? Doubts continue. Shortly before the book was published, he wrote to Victor Gollancz: 'It's the best you've ever read. Also don't forget it has a thesis. There's a purpose close behind me and it's treading on my tale.' What exactly was the 'thesis'? The clear themes of the book are that doctors should practice scientific, evidencebased medicine, that they should maintain and update their skills and knowledge, that they should work in partnership with each other, that the divide between GPs and hospital doctors should be broken and that the profit motive should be taken out of medicine. Cronin was a man of his time, a typical progressive of the 1930s. He believed in science. World War II saw the triumph of science and technology and the British public, exhausted and beggared by the long conflict were ready for change. The Citadel is a good bad book, or a bad good book, depending on one's perspective. It is worth reading for its pace and narrative, its acute portrayal of a dysfunctional medical system, its sense of moral outrage, its championing of science and its belief in progress. That enjoyment is marred by the plodding prose and its lack of wit. Nevertheless, only Cronin, with all his limitations as a writer, could have written it; it is difficult to conceive of a version of The Citadel written by Graham Greene or Evelyn Waugh. Re-reading The Citadel and Adventures in Two Worlds, it is clear that they are very 'readable'. The books, for all their faults, have this indefinable quality. He was undeniably a gifted storyteller. Cronin appeals to our better nature. One finishes a Cronin book with a faintly warm, sentimental glow, feeling a slightly better person. Cronin's books contain no ambiguity, no irony, no mockery. The Citadel is still worth reading today.

\section{REFERENCES}

Cronin AJ. The Citadel. London: Gollancz, 1937.

2 Cronin AJ. Adventures in two worlds. London: Gollancz, 1952.

3 Davies A. AJ Cronin: the man who created Dr Finlay. Richmond, Surrey:Alma; 20I I.

4 McKibbin R. Politics and the medical hero:AJ Cronin's The Citadel. English Historical Review 2008; CXXIII:65I-78. http://dx.doi. org/l0.1093/ehr/cen I62

5 Eyles L. The Times Literary Supplement. 1937 Aug 14.

6 Samuel R. North and south. London Review of Books 1995; 17:3-7.

7 NHS Scotland. A labour delivery [Internet]. Edinburgh: NHS Scotland [cited 2012 April 13]. Available from: http://www.60 yearsofnhsscotland.co.uk/history/birth-of-nhs-scotland la-labour-delivery.html

8 Frederick JT. AJ Cronin. The English Journal 194I; 30:70I-9. http:// dx.doi.org// 0.2307/805892

9 Hastings S. The secret lives of Somerset Maugham. London: John Murray; 2009.

10 Shields D. Reality hunger: a manifesto. New York: Knopf Publishing Group; 2010.

II Surawicz B, Jacobson B. Doctors in fiction: lessons from literature. Oxford: Radcliffe; 2009.

12 Cronin AJ. The judas tree. London: Gollancz; 196I. 